\title{
Metal hydride hydrogen storage and compression systems for energy storage technologies
}

\author{
Boris P. Tarasov ${ }^{a, *}$, Pavel V. Fursikov ${ }^{a}$, Alexey A. Volodin ${ }^{a}$, \\ Mikhail S. Bocharnikov ${ }^{a}$, Yustinas Ya Shimkus ${ }^{a}$, Aleksey M. Kashin ${ }^{b}$, \\ Volodymyr A. Yartys ${ }^{c}$, Stanford Chidziva ${ }^{d}$, Sivakumar Pasupathi ${ }^{d}$, \\ Mykhaylo V. Lototskyy ${ }^{d, * * *}$ \\ ${ }^{a}$ Institute of Problems of Chemical Physics (IPCP) of Russian Academy of Sciences, Chernogolovka, 142432, Russia \\ ${ }^{\mathrm{b}}$ InEnergy Group, Moscow, 115201, Russia \\ ${ }^{\mathrm{c}}$ Institute for Energy Technology, Kjeller NO, 2027, Norway \\ ${ }^{\mathrm{d}}$ HySA Systems Competence Centre, South African Institute for Advanced Materials Chemistry (SAIAMC), \\ University of the Western Cape, Bellville, 7535, South Africa
}

\section{H I G H L I G H T S}

- Use of metal hydride storage and compression in hydrogen energy storage systems.

- AB5- and AB2-type hydrides for hydrogen storage and compression applications.

- Development of the energy storage systems and their metal hydride based components.

\section{A R T I C L E I N F O}

\section{Article history:}

Received 29 February 2020

Received in revised form

6 July 2020

Accepted 9 July 2020

Available online 6 August 2020

\section{Keywords:}

Energy storage

Hydrogen

Metal hydrides

Hydrogen storage

Hydrogen compression

Integrated systems

\begin{abstract}
A B S T R A C T
Along with a brief overview of literature data on energy storage technologies utilising hydrogen and metal hydrides, this article presents results of the related R\&D activities carried out by the authors. The focus is put on proper selection of metal hydride materials on the basis of $\mathrm{AB}_{5}-$ and $\mathrm{AB}_{2}$-type intermetallic compounds for hydrogen storage and compression applications, based on the analysis of PCT properties of the materials in systems with $\mathrm{H}_{2}$ gas. The article also presents features of integrated energy storage systems utilising metal hydride hydrogen storage and compression, as well as their metal hydride based components developed at IPCP and HySA Systems.
\end{abstract}

(ङ) 2020 Hydrogen Energy Publications LLC. Published by Elsevier Ltd. All rights reserved.

\footnotetext{
* Corresponding author.

** Corresponding author.

E-mail addresses: tarasov@icp.ac.ru (B.P. Tarasov), mlototskyy@uwc.ac.za (M.V. Lototskyy). 


\section{Introduction}

Imbalance between energy production and consumption calls forth a great demand for efficient energy storage technologies [1], particularly when using renewables as primary energy sources [2]. The renewable energy sources are characterised by non-uniformity of power generation which fluctuates in time. In order to manage the fluctuations and utilize surplus electric power, the most promising way is in the use of hydrogen as an efficient energy carrier. When the surplus power is available, hydrogen is produced by water electrolysis. When the power generation is insufficient (e.g. during periods of low solar radiation), hydrogen is oxidized in a fuel cell (FC) to produce on-demand electricity.

The hydrogen based energy storage is beneficial in energy intensive systems ( $\geq 10 \mathrm{kWh}$ ) operating in a wide range of unit power (1-200 kW), especially when the footprint of the system has to be limited. The cost of ownership for backup power systems (10 kW/120 kWh) with hydrogen energy storage becomes lower than for alternative energy storage methods when the operating time exceeds 5 years [3].

The main challenge hindering implementation of the hydrogen energy storage systems is safe and efficient hydrogen storage and supply $[4,5]$.

Hydrogen storage in metal hydrides $(\mathrm{MH})$ based on reversible reaction of hydrogen with metals, alloys and intermetallic compounds is a promising option for small-tomedium-scale applications $\left(0.01-30 \mathrm{Nm}^{3} \mathrm{H}_{2}\right)$ [6-19]..$^{1}$ Apart from compact hydrogen storage at modest pressures, $\mathrm{MH}$ systems can utilize heat released during fuel cell operation for $\mathrm{H}_{2}$ desorption thus improving overall system efficiency [15,18-20]. The integration of MH in "electrolyser - fuel cell" energy system also allows for the efficient heat management providing end-user with heating and cooling in addition to electric power supply [21-25]. The available heat can also be used to drive metal hydride hydrogen compressor which provides storage of $\mathrm{H}_{2}$ as compressed gas. Thermally driven hydrogen compression utilising $\mathrm{MH}$ is particularly promising due to several other advantages including absence of moving parts, simplicity in design and operation, high purity of the delivered hydrogen [26,27].

There is a number of existing or recently completed projects worldwide related to the implementation of $\mathrm{MH}$ compressors for different applications. Typical examples include the EU-funded ATLAS-H2 [28], ATLAS-MHC [29], COSMHYC and COSMHYC XL [30] projects. Another example is a US DoE funded project aimed at the development of $\mathrm{MH}$ compressor for high-pressure (>875 bar) hydrogen delivery to refuel fuel cell powered vehicles [31]. The companies and institutions involved in the development of industrial-scale $\mathrm{MH}$ hydrogen compressors include HYSTORSYS AS (Norway, http:// hystorsys.no/), HYSTORE Technologies Ltd. (Cyprus, https:// www.hystoretechnologies.com/), South African Institute for

\footnotetext{
${ }^{1}$ These values represent typical hydrogen storage capacities of individual $\mathrm{MH}$ containers. Due to modular design of $\mathrm{MH}$ hydrogen storage tanks, they can be built as several containers connected in parallel thus providing the required amount of the stored $\mathrm{H}_{2}$. For example, a $7 \mathrm{Nm}^{3} \mathrm{H}_{2} \mathrm{MH}$ hydrogen storage tank used in Refs. [13] comprises of seven $\mathrm{MH}$ containers, $1 \mathrm{Nm}^{3} \mathrm{H}_{2}$ each.
}

Advanced Materials Chemistry (https://www.uwc.ac.za/ Faculties/NS/SAIAMC/) and HySA Systems Centre of Competence (http://hysasystems.com/), both hosted by the University of the Western Cape (South Africa), as well as SKTBE OAO (Russia, https://intelhim.ru/).

In this work, we summarise our results of development of integrated energy storage systems utilising metal hydride hydrogen storage and compression, as well as their metal hydride based components.

\section{Metal hydride materials}

Selection criteria of metal hydride materials for hydrogen storage and compression applications depend on a number of factors. First of all, the processes of hydride formation and decomposition must be reversible in the range of operating temperatures and hydrogen pressures specific for the application. ${ }^{2}$ Secondly, the material has to have high reversible hydrogen storage capacity at the operating conditions. These properties are determined by pressure - composition - temperature (PCT) characteristics in the systems of $\mathrm{H}_{2}$ gas with hydride-forming materials when the reversible capacity is associated with plateau width on the pressure - composition isotherm and the process direction (hydrogenation/ $\mathrm{H}_{2}$ uptake or dehydrogenation $/ \mathrm{H}_{2}$ release) depends on the relation between the actual $\mathrm{H}_{2}$ pressure and the plateau pressure at the actual temperature $[26,32]$. Plateau slope and hysteresis specific to the PCT behaviour of most of the real systems are very important for hydrogen compression applications since they result in the significant decrease of the compression ratio [26] and process efficiency [33] achieved in the given temperature range.

Other important properties of the $\mathrm{MH}$ materials for hydrogen storage and compression include fast hydrogen absorption and desorption kinetics, tolerance to poisoning with impurities in the feed $\mathrm{H}_{2}$, easy activation, cyclic stability, low cost and ease of the manufacturing $[26,32]$.

Table 1 presents summary of hydrogen storage performances of various metal hydride materials used in hydrogen storage and compression systems. The typical values were taken from previously published data analysed by the authors [7,15,26,34-41].

As it can be seen, most commonly used "low-temperature" intermetallic hydrides are characterised by weight hydrogen storage density between 1.5 and $1.9 \mathrm{wt} \%$, while the use of BCC solid solution alloys on the basis of $\mathrm{Ti}-\mathrm{Cr}-\mathrm{V}$ system allows to reach $\mathrm{H}$ storage capacity up to $\sim 2.5 \mathrm{wt} \%$; the latter materials, as well as some $\mathrm{AB}_{2}$-type intermetallics, can be used in "hybrid" hydrogen storage systems charged with $\mathrm{H}_{2}$ gas at high pressures and subzero temperatures [36,38]. Hydrogen storage materials on the basis of $\mathrm{MgH}_{2}$ are characterised by significantly higher weight hydrogen storage densities but require high operating temperatures that limits their application by only several cases when the high-temperature heat source, e.g. SOFC [22,23], is available.

\footnotetext{
${ }^{2}$ We do not consider hydrogen storage systems with off-board regeneration of the hydrogen storage material.
} 
Table 1 - Summary on performances of metal hydride materials for hydrogen storage and compression systems.

\begin{tabular}{|c|c|c|c|c|c|c|}
\hline \multirow[t]{2}{*}{ Parameter [units] } & & \multicolumn{5}{|c|}{ Typical range/value } \\
\hline & & $\mathrm{AB}_{5}$ & $\mathrm{AB}_{2}$ & $\mathrm{AB}^{\mathrm{a}}$ & BCC-Ti-Cr-V & $\mathrm{MgH}_{2}{ }^{\mathrm{b}}$ \\
\hline \multirow{5}{*}{$\begin{array}{l}\text { Operating temperatures }\left[{ }^{\circ} \mathrm{C}\right] \\
\text { Operating } \mathrm{H}_{2} \text { pressures [atm] } \\
\text { Gravimetric hydrogen storage density [wt.\%] } \\
\text { Volumetric hydrogen storage density }[\mathrm{kg} / \mathrm{L}]\end{array}$} & & 0 to 200 & -50 to 150 & 0 to 100 & -20 to 30 & 250 to 400 \\
\hline & & 0.1 to 500 & 1 to $>1000$ & 1 to 30 & 10 to 300 & 1 to 20 \\
\hline & & 1.50 & 1.90 & 1.75 & 2.5 & 5.5 to 7.5 \\
\hline & Material & 0.10 & 0.10 & 0.09 & 0.11 & 0.11 \\
\hline & System ${ }^{c}$ & 0.063 & 0.061 & 0.055 & 0.069 & 0.066 \\
\hline \multicolumn{7}{|c|}{$\begin{array}{l}\text { a TiFe and related intermetallics. } \\
\text { b Including alloys and nanocomposites on the basis of Mg. } \\
\text { c According to the analysis of reference data presented in Ref. [35]. }\end{array}$} \\
\hline
\end{tabular}

In spite of very high volumetric hydrogen storage density in the considered hydride materials significantly (typically by half) exceeding the density of liquid hydrogen $(\sim 0.07 \mathrm{~kg} / \mathrm{L})$, the volumetric hydrogen storage density on the system level will be lower due to the limited safe densities of filling the materials in the containment, as well as differences in the densities of the parent materials [35]. As a result, the system volumetric hydrogen storage densities will take similar (though still high) values for the different materials (last row in Table 1), and for stationary energy storage systems the material selection criteria will be mainly related to conditions and performances of their operation (e.g. pressure/temperature ranges, ease of activation, hydrogen absorption/desorption kinetics, cycle stability) rather than the hydrogen storage densities.

$A B_{5}-$ and $A B_{2}$-type intermetallics are the most frequently used hydride materials in hydrogen storage and its supply to fuel cell systems [15], as well as in hydrogen compression applications [26]. The main reason for that is the tunability of hydrogen sorption properties of these types of materials by small variations of their composition. This gives an opportunity to align the pressure/temperature operating performances of these materials with the application conditions.

$\mathrm{AB}_{5}$-type intermetallics where $\mathrm{A}=$ rare earth metal (RE), $\mathrm{B}$ $=\mathrm{Ni}, \mathrm{Co}, \mathrm{Al}, \mathrm{Mn}, \mathrm{Sn}$, etc., are characterised by easy activation, fast kinetics of hydrogen absorption and desorption, and relatively high stability of hydrogen sorption properties during cyclic hydrogenation/dehydrogenation (including the operation in $\mathrm{H}_{2}$ gas containing impurities of oxygen and water vapours in moderate concentrations).

For the parent intermetallic, $\mathrm{LaNi}_{5}$, the plateau pressure is equal to $1.8 \mathrm{~atm}$ at $\mathrm{T}=25^{\circ} \mathrm{C}$ [32]. The plateau pressure can be decreased by the substitution of Ni with $\mathrm{Al}, \mathrm{Sn}, \mathrm{Mn}$, Co, while the substitution of La with $\mathrm{Ce}$ (or $\mathrm{Mm} / \mathrm{mischmetal),} \mathrm{Y}$, Ca results in the pressure increase [26,32,42-45]. The substitution with Sn [42], $\mathrm{Al} \mathrm{[43],} \mathrm{or} \mathrm{Ce} \mathrm{[45]} \mathrm{also} \mathrm{improves} \mathrm{stability} \mathrm{of} \mathrm{LaNi}_{5}$ towards disproportionation during prolonged pressure/temperature cycling while Ca substitution worsens the cycle stability [45].

As a rule, pressure - composition isotherms in $\mathrm{H}-\mathrm{AB}_{5}$ systems exhibit one flat plateau with not very high $\mathrm{H}_{2}$ absorption-desorption hysteresis which, however, increases in the substituted alloys. As an example, for $\mathrm{LaNi}_{5}$ at $\mathrm{T}=20-25^{\circ} \mathrm{C}$, the ratio of $\mathrm{H}_{2}$ absorption $\left(\mathrm{P}_{\mathrm{A}}\right)$ and desorption $\left(\mathrm{P}_{\mathrm{D}}\right)$ pressures at the $\mathrm{H}$ concentration corresponding to plateau midpoint is about 1.45; for $\mathrm{La}_{0.5} \mathrm{Ce}_{0.5} \mathrm{Ni}_{5}$ the ratio $\mathrm{P}_{\mathrm{A}} / \mathrm{P}_{\mathrm{D}}$ increases to 3.55 at the same conditions [45].

$\mathrm{AB}_{2}$ type materials used for $\mathrm{H}_{2}$ storage and compression are C14 (less frequently, C15 and C36) Laves phase intermetallic compounds mostly formed by $\mathrm{Ti}$ and $\mathrm{Zr}$ as A component, and $B$ component is usually represented by several transition metals including $\mathrm{Mn}, \mathrm{Cr}, \mathrm{Fe}, \mathrm{V}$, etc. $\mathrm{AB}_{2 \pm \mathrm{X}}$ intermetallics are even more flexible than $A_{5}$ 's in the tuning of their PCT properties by the variation of the composition $[26,46,47]$. The equilibrium $\mathrm{H}_{2}$ desorption pressures for hydrides of the $\mathrm{AB}_{2}-$ type alloys cover practically unlimited range: from $\sim 3 \cdot 10^{-3}$ atm at $\mathrm{T}=227^{\circ} \mathrm{C}$ for $\mathrm{ZrV}_{2}$ (calculated from the values $\Delta \mathrm{S}^{\circ}=-88.4 \mathrm{~J} /\left(\mathrm{mol} \mathrm{H}_{2} \mathrm{~K}\right), \Delta \mathrm{H}^{\circ}=-78 \mathrm{~kJ} / \mathrm{mol} \mathrm{H}_{2}$ [48]) to $>5000 \mathrm{~atm}$ at the room temperature for $\mathrm{TiFe}_{2}$ (calculated in Ref. [49]). The thermal stability of the hydrides (the absolute value of their formation enthalpy, $\left.\left|\Delta \mathrm{H}^{\circ}\right|\right)$ can be increased by the increase of $\mathrm{Zr}$ :Ti atomic ratio from the A-side and/or by introducing $\mathrm{V}$ as one of the $\mathrm{B}$-components. Conversely, the $\mathrm{AB}_{2}$ hydride stability can be decreased by the decrease of the Zr:Ti ratio, decrease of $\mathrm{V}$ content or its elimination, increase of Fe content, as well as increase of stoichiometric B:A ratio. The balancing between the content of other components (e.g. $\mathrm{Cr}$ and $\mathrm{Mn}$ ) allows to further modify the PCT properties $[46,47,50,51]$. Usually $\mathrm{H}-\mathrm{AB}_{2}$ interaction is characterised by a sloping plateaux on the pressure - composition isotherms and small hysteresis, with values of $\mathrm{P}_{\mathrm{A}} / \mathrm{P}_{\mathrm{D}}$ at $\mathrm{T}=20-25^{\circ} \mathrm{C}$ in the plateau midpoint ranging from 1.14 to 1.46 , even in the multi-component alloys when $\mathrm{A}=\mathrm{Ti}_{\mathrm{x}} \mathrm{Zr}_{1-\mathrm{x}}(\mathrm{x}=0.15-0.85)$ and $B$ is a mixture of $4-5$ transition metals including $\mathrm{Cr}, \mathrm{Mn}, \mathrm{Ni}, \mathrm{Fe}$ and $\mathrm{V}[47,52]$.

The $\mathrm{AB}_{2}$-type alloys are generally less easy activated than $\mathrm{AB}_{5}$ ones, and for facilitation of their activation they can be doped by small amounts ( 1 at\%) of rare earth elements [53]. Once activated, they exhibit excellent hydrogenation/dehydrogenation kinetics and a good cycle stability [32,54]. Their components are less expensive than the ones used for the making of RE-based $A_{5}$ 's, but manufacturing of the $A_{2}$-type alloys experiences some metallurgical difficulties due to higher melting temperatures, high reactivity of the components and other factors [32,55]. When activated, the $\mathrm{AB}_{2}$-type alloys, particularly those ones which contain $\mathrm{Zr}$ and $\mathrm{Mn}$, are highly pyrophoric; these materials are also more sensitive to impurities in $\mathrm{H}_{2}$ than $\mathrm{AB}_{5}$ 's [32].

The $\mathrm{La}_{1-\mathrm{X}} \mathrm{RE}_{\mathrm{X}} \mathrm{Ni}_{5} \quad(\mathrm{RE}=\mathrm{Ce}, \mathrm{Mm})$ and $\mathrm{Ti}_{1-\mathrm{X}} \mathrm{Zr}_{\mathrm{X}}$ $(\mathrm{Mn}, \mathrm{Cr}, \mathrm{Fe}, \mathrm{V}, \mathrm{Ni})_{2}$ intermetallics were used by the authors in a number of $\mathrm{MH}$ hydrogen storage systems operating at nearambient temperatures and hydrogen pressures above $1 \mathrm{~atm}$, as well as for thermally-driven $\mathrm{H}_{2}$ compression from 3 to 35 to $100-150 \mathrm{~atm}\left(\mathrm{AB}_{5}\right)$ and from 50 to 100 to $200-500 \mathrm{~atm}\left(\mathrm{AB}_{2}\right)$ at $\mathrm{T}=15-150^{\circ} \mathrm{C}$ (will be discussed in Sections Hydrogen storage and Hydrogen compression below). 
For the determination of hydrogen concentrations in the studied materials at variable temperatures and $\mathrm{H}_{2}$ pressures, we applied earlier developed model of phase equilibria in metal - hydrogen systems [56]. Within this model, the pressure - composition isotherms were constructed as pseudoconvolutions of an "ideal" isotherm built according to the model of van der Waals lattice gas (hydrogen - metal phase diagram), with two modified asymmetric pseudo Voight distribution functions (one for $\mathrm{H}$ desorption and another for $\mathrm{H}$ absorption) modelling plateau slope and hysteresis. In doing so, the median of the absorption distribution was shifted from the one of the desorption distribution towards higher pressures, by the value related to a minimum of a hysteresis free energy loss and an excessive chemical potential of hydrogen in over-saturated $\alpha$-solid solution. According to the model, the PCT diagram as a whole is described by a set of parameters (16 per a plateau segment) some of which (e.g. critical temperature, hysteresis energy loss, enthalpy and entropy of hydride formation) have a clear physical sense and others, describing temperature- and concentration-dependent plateau slope, are semi-empirical.

Table 2 presents characteristics of the studied $\mathrm{MH}$ materials including hydrogen absorption capacities at the room temperature $\left(20^{\circ} \mathrm{C}\right)$ and the specified $\mathrm{H}_{2}$ pressures, as well as temperatures which correspond to the specified plateau pressures of $\mathrm{H}_{2}$ desorption at $\mathrm{H}$ concentrations which correspond to the plateau midpoint. The presented values were calculated from hydrogen absorption and desorption isotherms for the specified materials built at different temperatures using the authors' experimental PCT data further processed by the model [56]; so as the fitted model parameters allowed to build the isotherm at any selected temperature.

As it can be seen from Table 2, the $\mathrm{AB}_{5}$-type materials with different $\mathrm{Ce} / \mathrm{La}$ ratios and $\mathrm{AB}_{2}$-type ones with different $\mathrm{Zr} / \mathrm{Ti}$ ratios (both from the $A$ side) allow to develop on their basis various hydrogen storage and compression systems operating in various ranges of temperatures and $\mathrm{H}_{2}$ pressures. However, the presented data do not allow to estimate the useable hydrogen storage capacities for the hydrogen storage, as well as cycle productivities of the hydrogen compressors. These estimations can also be derived from the PCT diagrams of the used MH materials and will be presented in the next sections. The calculations of reversible hydrogen storage capacities or the materials assumed to be close to the useable hydrogen storage capacities of hydrogen storage systems (Section Hydrogen storage) or cycle productivities of $\mathrm{H}_{2}$ compressors (Section Hydrogen compression), were carried out similarly, from the modelled hydrogen absorption (ABS) and desorption (DES) isotherms (see example in Fig. 1 (D)).

\section{Hydrogen storage}

Fig. $1(\mathrm{~A}-\mathrm{C})$ shows the useable (reversible) hydrogen storage capacities for $\mathrm{AB}_{5}$ - and $\mathrm{AB}_{2}$-type materials in the hydrogen storage systems which were developed at the author's institutions.

When charged with $\mathrm{H}_{2}$ at $\mathrm{T}=20^{\circ} \mathrm{C}$ and the pressure corresponding to the end of $\mathrm{H}$ absorption plateau on the pressure - composition isotherm, all the materials allow to use $~ 90 \%$ of

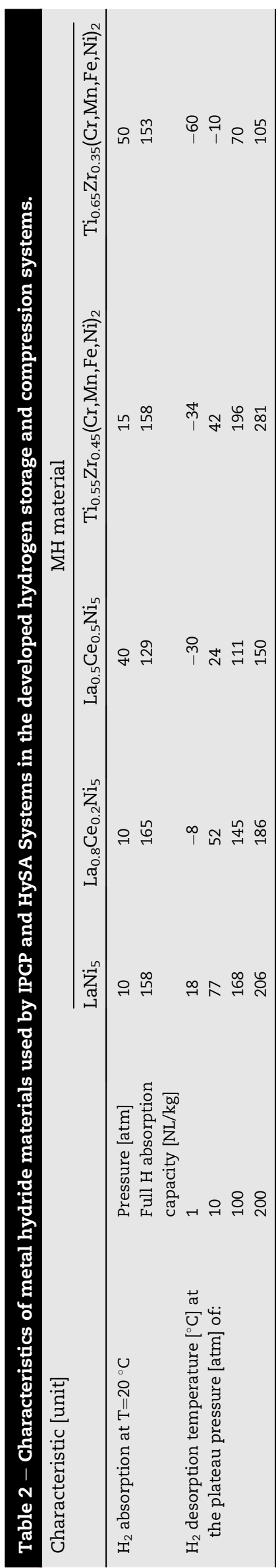



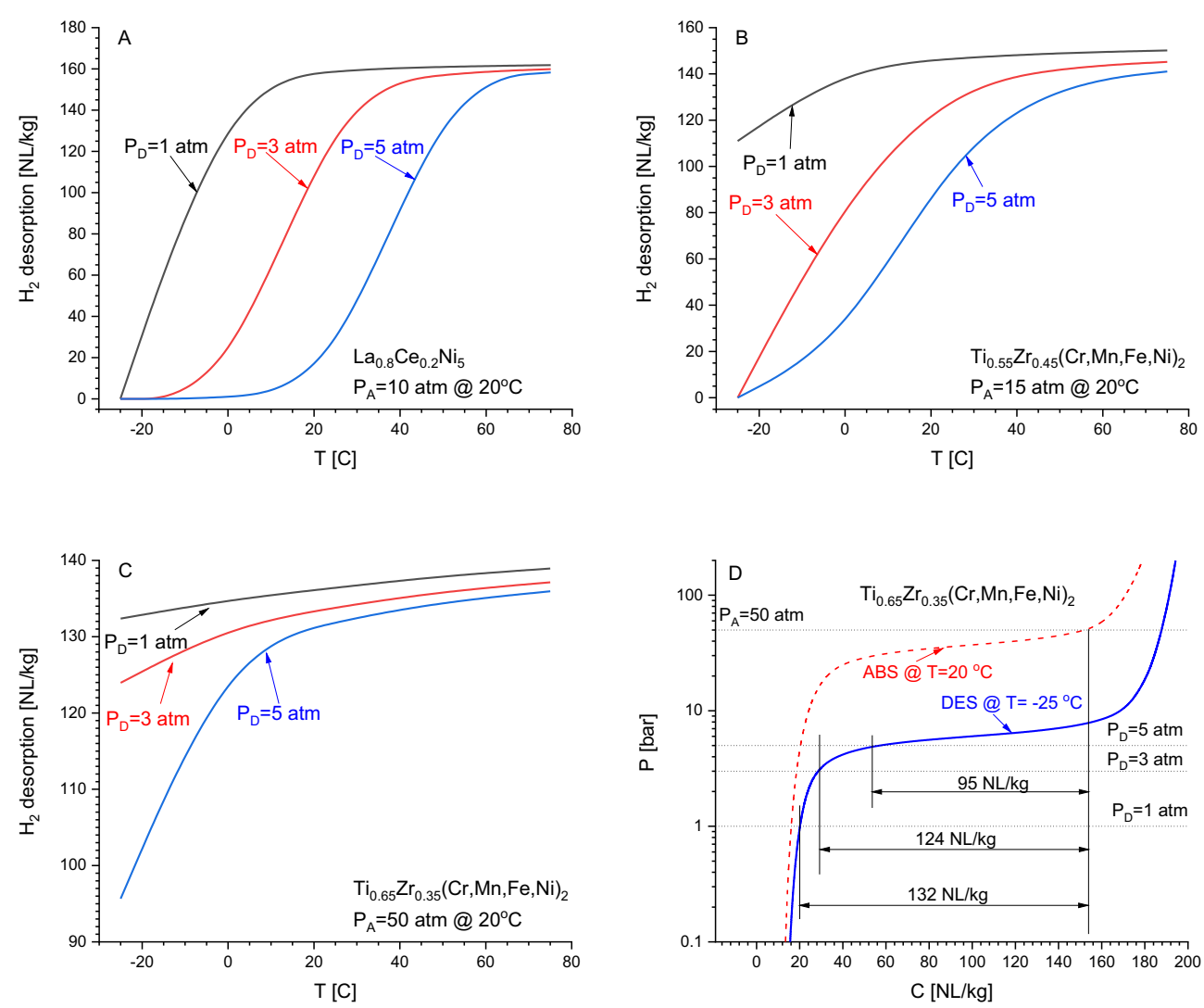

Fig. 1 - A-C: amounts of desorbed $\mathrm{H}_{2}$ (useable $\mathrm{H}$ storage capacity) for some $\mathrm{AB}_{5}$ - and $A B_{2}$-type materials as functions of operating temperature at different $\mathrm{H}_{2}$ desorption pressures $\left(\mathrm{P}_{\mathrm{D}}\right) ; \mathrm{H}_{2}$ absorption pressures $\left(\mathrm{P}_{A}\right)$ are specified in the graphs. $\mathrm{D}$ : Example of determination of the amounts of the desorbed $\mathrm{H}_{2}$ for $\mathrm{Ti}_{0.65} \mathrm{Zr}_{0.35}(\mathrm{Cr}, \mathrm{Mn}, \mathrm{Fe}, \mathrm{Ni})_{2}(\mathrm{C})$ at $\mathrm{T}=-25{ }^{\circ} \mathrm{C}$.

their full capacity at $\mathrm{T}=50^{\circ} \mathrm{C}$ and $\mathrm{P}\left(\mathrm{H}_{2}\right)=5$ atm that is enough to supply hydrogen to low-temperature PEM FC stack using the heat released during its operation for the heating of the $\mathrm{MH}$ bed [15]. Moreover, most of the $\mathrm{MH}$ materials are able to desorb $\mathrm{H}_{2}$ at pressures above atmospheric and subzero temperatures (Fig. 1(D)) thus making it possible to start-up the FC power system even during winter time.

It has to be noted that the useable hydrogen storage capacities of $\mathrm{MH}$ materials shown in Fig. 1 are the maximum theoretical values. Real amounts of $\mathrm{H}_{2}$ supplied from the $\mathrm{MH}$ to the FC stack also depend on the hydrogen supply flow rate and, in turn, the stack power. At the high rate, the endothermic $\mathrm{H}_{2}$ desorption results in the cooling the $\mathrm{MH}$ bed thus slowing the $\mathrm{H}_{2}$ release down. As a result, the useable $\mathrm{H}_{2}$ capacity of the $\mathrm{MH}$ at a specified rate of $\mathrm{H}_{2}$ desorption/stack power will decrease; this effect can be minimised by the improvement of the heat exchange between the $\mathrm{MH}$ and the heating fluid, as well as by other engineering solutions [12].

Table 3 summarises performances of several metal hydride hydrogen storage units for hydrogen energy storage systems developed at the Institute of Problems of Chemical Physics of Russian Academy of Sciences (IPCP) and "Hydrogen South Africa" System Integration and Technology Validation Centre of Competence (HySA Systems). The units use $\mathrm{MH}$ materials on the basis of $\mathrm{La}_{1-X} \mathrm{RE}_{\mathrm{X}} \mathrm{Ni}_{5}(\mathrm{RE}=\mathrm{Ce}, \mathrm{Mm})$ and multicomponent $\mathrm{AB}_{2}$-type alloys $(\mathrm{A}=\mathrm{Ti}+\mathrm{Zr})$ characterised by $\mathrm{H}_{2}$ equilibrium desorption pressures from 2.2 to $40 \mathrm{~atm}$ at the room temperature and can supply $\mathrm{H}_{2}$ to PEM FC stacks, $1-15 \mathrm{~kW}$ in the nominal power. The tanks number 1, 2 and 5 utilising more stable $\mathrm{MH}$ materials can be charged directly from a PEM electrolyser with $\mathrm{H}_{2}$ output pressure 15-20 atm while for the tanks number 3 and 4 the feed $\mathrm{H}_{2}$ should be compressed to 50 atm or higher, if a fast $\mathrm{H}_{2}$ charge is necessary.

The units developed by IPCP (number 1-3; Fig. 2) use standard composite cylinders (carbon- or glass-fibre wounded stainless steel liner) as a containment heated and cooled from the outside by natural air convection or flow of heating/cooling liquid; in the latter case the containment is enveloped in a stainless steel heating/cooling jacket. This solution is lightweight, simple and inexpensive but it is characterised by a poor heat exchange between the $\mathrm{MH}$ and the heating/cooling fluid that results in rather slow $\mathrm{H}_{2}$ charge and discharge.

The HySA Systems MH tanks (number 4, 5) use multiple $\mathrm{MH}$ containers, $\sim 40 \mathrm{~mm}$ in internal diameter, equipped with inner copper fins (see Fig. 3 (A)) and heated/cooled from the outside. Additionally, a small amount of expanded natural graphite was added to the $\mathrm{MH}$ powder that allowed to increase the safe $\mathrm{MH}$ filling density ${ }^{3}$ and to further improve the heat transfer in the $\mathrm{MH}$

\footnotetext{
${ }^{3}$ The limitation of the filling density is necessary to avoid appearance of stresses in the container walls due to expansion of the $\mathrm{MH}$ material upon hydrogenation. As a rule, the filling density of $\mathrm{MH}$ powders into HySA Systems containers for hydrogen storage and compression was about $55 \%$ of the density of the material in the hydrogenated state. The maximum safe limit of the filling density was reported as $61 \%$ (50\% typically applied) [57].
} 


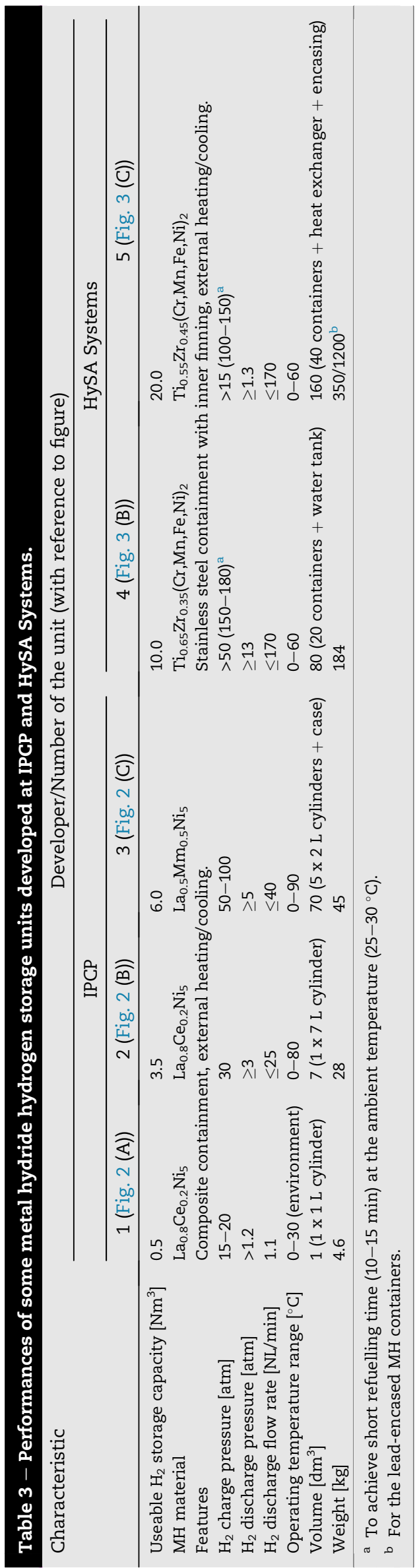

bed. Though this solution is more labour-consuming and expensive, it allowed to significantly increase $\mathrm{H}_{2}$ supply rate to the fuel cell stack whose cooling system is thermally coupled with the heating system of the $\mathrm{MH}$ tank. A significant increase of the tank weight associated with the heat transfer improvements is not an issue for the stationary and even some special mobile applications. For example, in the HySA Systems MH tank (number 5; Fig. 3(C)) initially designed for hydrogen storage on-board fuel cell forklift, the weight was even intentionally increased by encasing the $\mathrm{MH}$ containers in lead to provide counterbalance weight necessary for the safe forklift operation [58].

\section{Hydrogen compression}

When hydrogen energy storage system stores hydrogen in compressed gas cylinders or in metal hydrides whose equilibrium $\mathrm{H}_{2}$ absorption pressure at the operating temperature for $\mathrm{H}_{2}$ charge exceeds $\mathrm{H}_{2}$ pressure provided by electrolyser, hydrogen compression is necessary. As it was mentioned in the Introduction, the use of $\mathrm{MH}$ for the $\mathrm{H}_{2}$ compression brings a number of benefits including the increase of the overall system efficiency by the use of waste heat released during operation of the electrolyser.

Fig. 4(A-E) presents dependencies of cycle productivities of $\mathrm{MH}$ compression on the suction $\left(\mathrm{P}_{\mathrm{L}}\right)$ and discharge $\left(\mathrm{P}_{\mathrm{H}}\right)$ pressures, at the cooling temperature $\mathrm{T}_{\mathrm{L}}=20{ }^{\circ} \mathrm{C}$ and heating temperature $\mathrm{T}_{\mathrm{H}}=150^{\circ} \mathrm{C}$. The graphs similar to the ones presented in the review on $\mathrm{MH} \mathrm{H}_{2}$ compressors (see Refs. [26], Fig. 4) were built from the calculated isotherms (see Section Metal hydride materials for the details) for $\mathrm{H}_{2}$ absorption at $\mathrm{T}_{\mathrm{L}}$ and $\mathrm{H}_{2}$ desorption at $\mathrm{T}_{\mathrm{H}}$ (see example in Fig. $4(\mathrm{~F})$ ).

As it was shown in Refs. [26], if $\mathrm{P}_{\mathrm{L}}$ exceeds the plateau pressure at $T=T_{L}$, very high compression ratios, $P_{H} / P_{L}$, can be achieved even for quite stable $\mathrm{MH}$, though at low cycle productivities; and at $\mathrm{P}_{\mathrm{H}} / \mathrm{P}_{\mathrm{L}}$ below $\sim 5$ the cycle productivity exceeds $\sim 70 \%$ of the full capacity of the $\mathrm{MH}$ material (see examples in Fig. 4). As it can be seen from Fig. 4(A-C), at $\mathrm{T}_{\mathrm{L}}=20^{\circ} \mathrm{C}$ and $\mathrm{T}_{\mathrm{H}}=150^{\circ} \mathrm{C}$ and the target cycle productivity of $100 \mathrm{NL} / \mathrm{kg}, \mathrm{LaNi}_{5}$ can provide $\mathrm{H}_{2}$ compression from 3 to $25 \mathrm{~atm}$, $\mathrm{La}_{0.8} \mathrm{Ce}_{0.2} \mathrm{Ni}_{5}$ from 10 to $100 \mathrm{~atm}$, and $\mathrm{La}_{0.5} \mathrm{Ce}_{0.5} \mathrm{Ni}_{5}$ from 40 to 170 atm. For the $\mathrm{AB}_{2}$-type $\mathrm{H}_{2}$ compression alloys (Fig. 4(D and $\mathrm{E})$ ), the corresponding ranges of the operating pressures $\left(\mathrm{P}_{\mathrm{L}}-\mathrm{P}_{\mathrm{H}}\right)$ are 50-270 and 70-350 atm, for $\mathrm{Ti}_{0.65} \mathrm{Zr}_{0.35}(-$ $\mathrm{Cr}, \mathrm{Mn}, \mathrm{Fe}, \mathrm{Ni})_{2}$ and $\mathrm{Ti}_{0.7} \mathrm{Zr}_{0.3}(\mathrm{Cr}, \mathrm{Mn}, \mathrm{Fe}, \mathrm{Ni})_{2}$, respectively. Note that the values specified above are only estimations based on the analysis of PCT data for the MH materials and can vary depending on the design features of the $\mathrm{MH}$ compressors and their operating conditions. However, for the properly designed compressor the deviations are not very high. For example, for the two-stage compressor TSC2-3.5/150 $\left(\mathrm{T}_{\mathrm{L}}=15{ }^{\circ} \mathrm{C}\right.$, $\mathrm{T}_{\mathrm{H}}=150^{\circ} \mathrm{C}, 15 \mathrm{Nm}^{3} / \mathrm{h}$ ) developed by Russian company SKTBE under IPCP supervision, the cycle productivity of the first stage $\left(\mathrm{LaNi}_{5}, \mathrm{P}_{\mathrm{L}}=3.5 \mathrm{~atm}, \mathrm{P}_{\mathrm{H}} \sim 35 \mathrm{~atm}\right)$ was about $75 \mathrm{NL} / \mathrm{kg}$, and for the second stage $\left(\mathrm{La}_{0.5} \mathrm{Ce}_{0.5} \mathrm{Ni}_{5}, \mathrm{P}_{\mathrm{L}} \sim 35 \mathrm{~atm}, \mathrm{P}_{\mathrm{H}}=150 \mathrm{~atm}\right)$ about $100 \mathrm{NL} / \mathrm{kg}$, taking into account cycle time $38 \mathrm{~min}$ and three $\mathrm{H}_{2}$ compression sections in the compressor [27].

A summary of features and performances of $\mathrm{MH}$ hydrogen compressors for hydrogen energy storage systems developed 


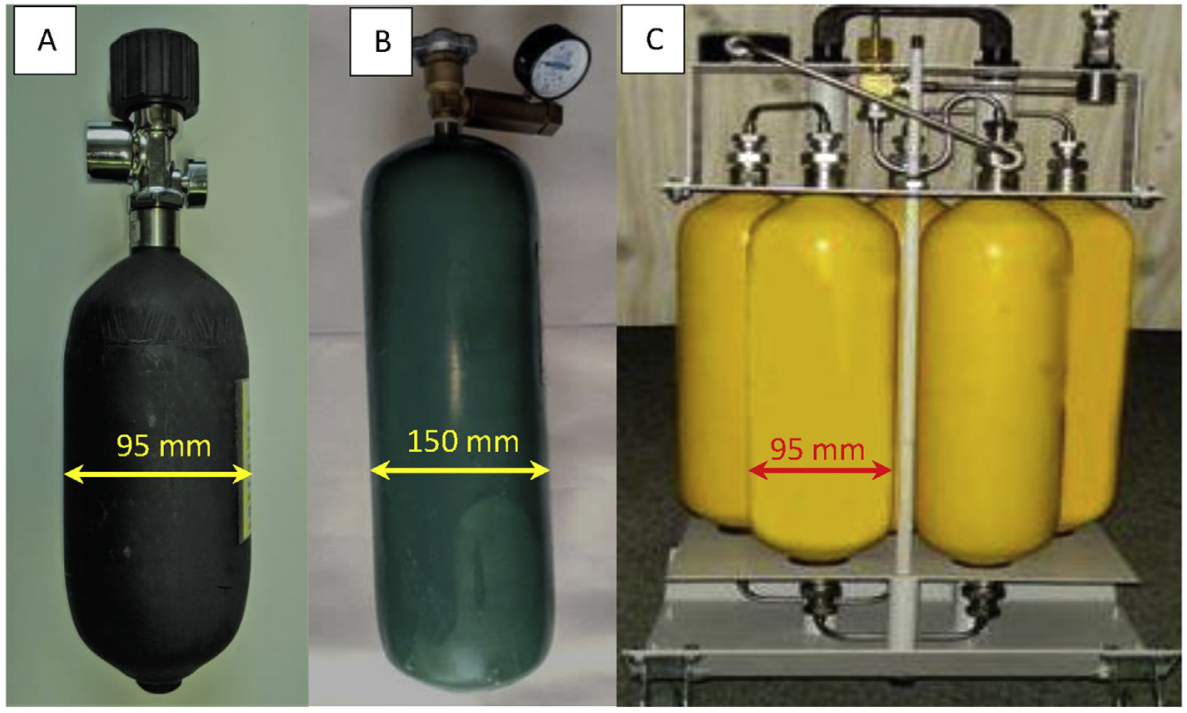

Fig. 2 - Examples of $\mathrm{MH} \mathrm{H}_{2}$ storage tanks with storage capacity of 0.5 (A), 3.5 (B) and 6 (C) $\mathrm{Nm}^{3} \mathrm{H}_{2}$ developed at IPCP.

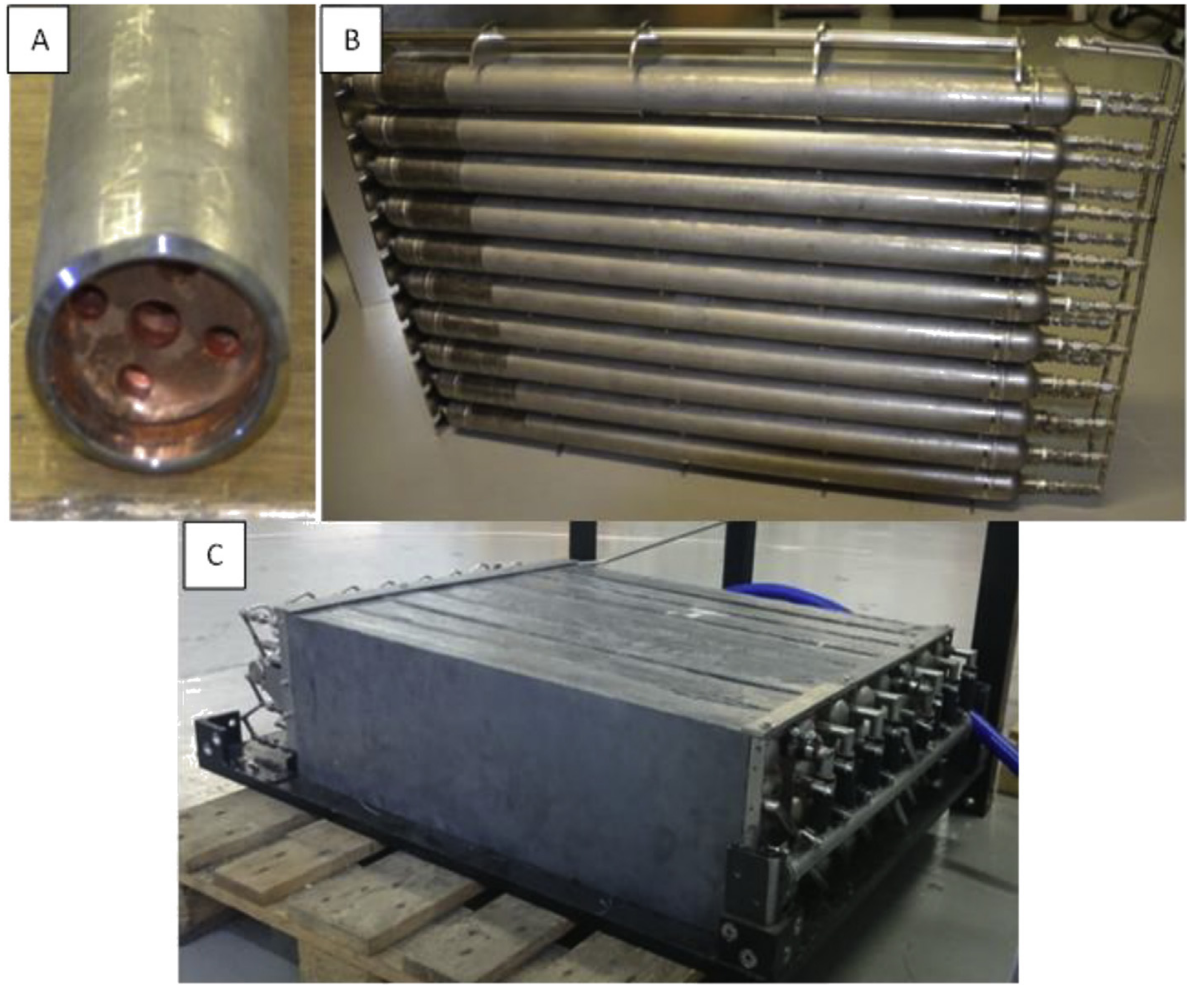

Fig. 3 - Inner layout of HySA Systems $\mathrm{MH}$ container for $\mathrm{H}_{2}$ storage (A), assembly of the containers in $10 \mathrm{Nm}^{3}(\mathrm{~B})$ and $20 \mathrm{Nm}^{3}$ $\mathrm{H}_{2}$ (C) storage tanks.

under the authors' supervision has been presented in Ref. [27], as well as in a review [59] and references therein.

\section{System integration}

Table 4 presents main features and performances of two integrated hydrogen energy storage systems developed under supervision of IPCP (number 1) and HySA Systems (number 2).
Both systems use gas cylinder packs as main and $\mathrm{MH}$ hydrogen storage units as auxiliary hydrogen storage facilities. The gas cylinder pack is filled with $\mathrm{MH}$ compressor during system operation. The MH units can be charged either from the output of the electrolyser (see example for system number 2 in Fig. 5) or, if the output pressure is not high enough (system number 1), from the discharge line of the compressor via reducer. When charged, the smaller-scale $\mathrm{MH}$ units can be moved to other premises where $\mathrm{H}_{2}$ consuming fuel cell stacks 

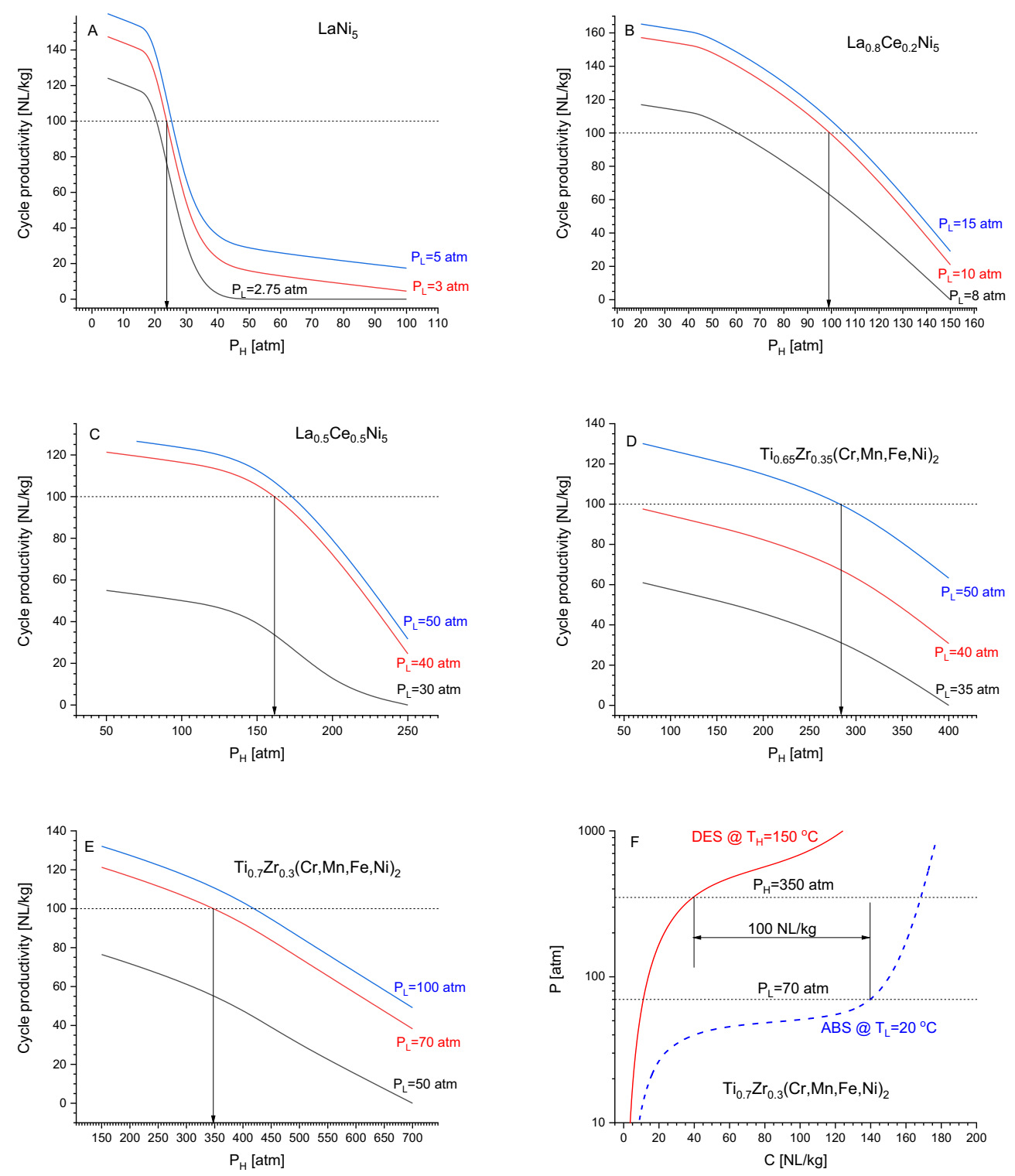

Fig. 4 - A-E: cycle productivities of $M H$ hydrogen compressors for $A^{-} B_{5}$ and $A_{2}$-type materials used in $M H H_{2}$ compressors developed at IPCP and HySA Systems as functions of suction $\left(P_{L}\right)$ and discharge $\left(P_{H}\right)$ pressures at $T_{L}=20^{\circ} \mathrm{C}$ and $T_{H}=150{ }^{\circ} \mathrm{C}$. F: Example of determination of the cycle productivity for $\mathrm{Ti}_{0.7} \mathrm{Zr}_{0.3}(\mathrm{Cr}, \mathrm{Mn}, \mathrm{Fe}, \mathrm{Ni})_{2}(\mathrm{E})$. The values of $\mathrm{P}_{\mathrm{H}}$ are shown in $\mathrm{X}$-axes while the values of $P_{L}-$ as curve labels.

are installed. Alternatively, the bigger $\mathrm{MH}$ tanks (e.g. number 4, 5 in Table 3) can be permanently connected to a line supplying hydrogen to the fuel cell stacks. These tanks can also be used as buffers between the output of the electrolyser and the input of the $\mathrm{MH}$ compressor (Fig. 5).

System number 2 (HySA Systems; see Fig. 5) provides SAIAMC research facilities with hydrogen from $\mathrm{H}_{2}$ cylinder pack equipped with a gas distributing system connected to three pipelines for $\mathrm{H}_{2}$ supply to (i) fuel cell testing stations (10 atm), (ii) other experimental facilities consuming mediumpressure hydrogen (80 atm) and (iii) hydrogen dispensing (30-200 atm) for the refuelling of fuel cell vehicle prototypes (e.g. forklifts).

Though a big number of the integrated energy systems "electrolyser - metal hydride - fuel cell" has been developed up to date, they mainly used metal hydrides for hydrogen storage (see e.g. Refs. $[10,13,14,16,19])$. As to the authors' knowledge, there exists one development related to the integration of the $\mathrm{MH}$ compressor in a hydrogen-based power system undertaken under support of EU-funded ATLAS-MHC project [60]. The corresponding development of a prototype $\mathrm{MH}$ compressor for this application including technoeconomic forecast was reported in Ref. [61]; a brief performance summary for the prototype was presented in the review [59]. The compressor developed by HYSTORE Technologies Ltd. (Cyprus) provides $\mathrm{H}_{2}$ compression from 7 to $220 \mathrm{~atm}$ with a productivity up to $2.5 \mathrm{Nm}^{3} / \mathrm{h}$ that is close to the characteristics of the $\mathrm{MH}$ compressor integrated in HySA Systems hydrogen production, storage and distribution system (number 2 in Table 4, Fig. 5). The advantage of the 
Table 4 - Integrated energy storage systems developed under supervision of IPCP and HySA Systems.

\begin{tabular}{|c|c|c|c|}
\hline \multicolumn{2}{|c|}{ Features, main components } & \multicolumn{2}{|c|}{ Number/developer } \\
\hline & & 1/IPCP [27] & 2/HySA Systems (Fig. 5) \\
\hline \multicolumn{2}{|c|}{ Primary energy source } & Grid, solar panels, wind turbine (25 kW) & Grid, solar panels (4.5 kW) \\
\hline \multirow[t]{4}{*}{ Electrolyser } & Type & Alkaline & PEM \\
\hline & Power $[\mathrm{kW}]$ & 23 & 4.3 \\
\hline & $\mathrm{H}_{2}$ output pressure [atm] & 4 & $\leq 20$ \\
\hline & $\mathrm{H}_{2}$ output flow rate $\left[\mathrm{Nm}^{3} / \mathrm{h}\right]$ & 15 & 2 \\
\hline \multirow{9}{*}{$\mathrm{H}_{2}$ storage } & Type & Gas cylinders $^{\mathrm{a}}+\mathrm{MH}$ & Gas cylinders ${ }^{a}$ \\
\hline & $\mathrm{H}_{2}$ charge pressure [atm] & Gas cylinders: 150 & Gas cylinders: 200 \\
\hline & & MH units: $30-100$ & MH unit: $15-20$ \\
\hline & $\mathrm{H}_{2}$ supply pressure [atm] & Gas cylinders: up to 150 & 10 (FC stacks test stations) \\
\hline & & MH units: $2-5$ & $\begin{array}{l}80 \text { (other } \mathrm{H}_{2} \text { consuming facilities) } \\
30-200 \text { (FCV refuelling) }\end{array}$ \\
\hline & Capacity $\left[\mathrm{Nm}^{3}\right]$ & Gas cylinders: 72 & Gas cylinders: 180 \\
\hline & & MH tanks: $3.5-6$ & MH tank: 20 \\
\hline & $\mathrm{H}_{2}$ supply flow rate $[\mathrm{NL} / \mathrm{min}]$ & Gas cylinders: unlimited & Gas cylinders: unlimited \\
\hline & & MH units: $20-40$ & MH unit: up to 170 \\
\hline \multirow{3}{*}{ MH $\mathrm{H}_{2}$ compressor } & Pressure range [atm] & $3.5-150$ & $3-200$ \\
\hline & Temperature range $\left[{ }^{\circ} \mathrm{C}\right]$ & $15-160$ & $20-130$ \\
\hline & Productivity $\left[\mathrm{Nm}^{3} / \mathrm{h}\right]$ & 15 & 5 \\
\hline \multicolumn{2}{|l|}{ Hydrogen consumer } & Various PEM FC stacks (1-10 kW) & $\begin{array}{l}\text { PEM FC stacks test stations (up to } 30 \mathrm{~kW} \text { ) } \\
\text { FCV refuelling }\end{array}$ \\
\hline
\end{tabular}

${ }^{a}$ The gas cylinders of standard size (50 $\mathrm{dm}^{3}$ in the volume) connected in parallel (up to 18 per a pack).

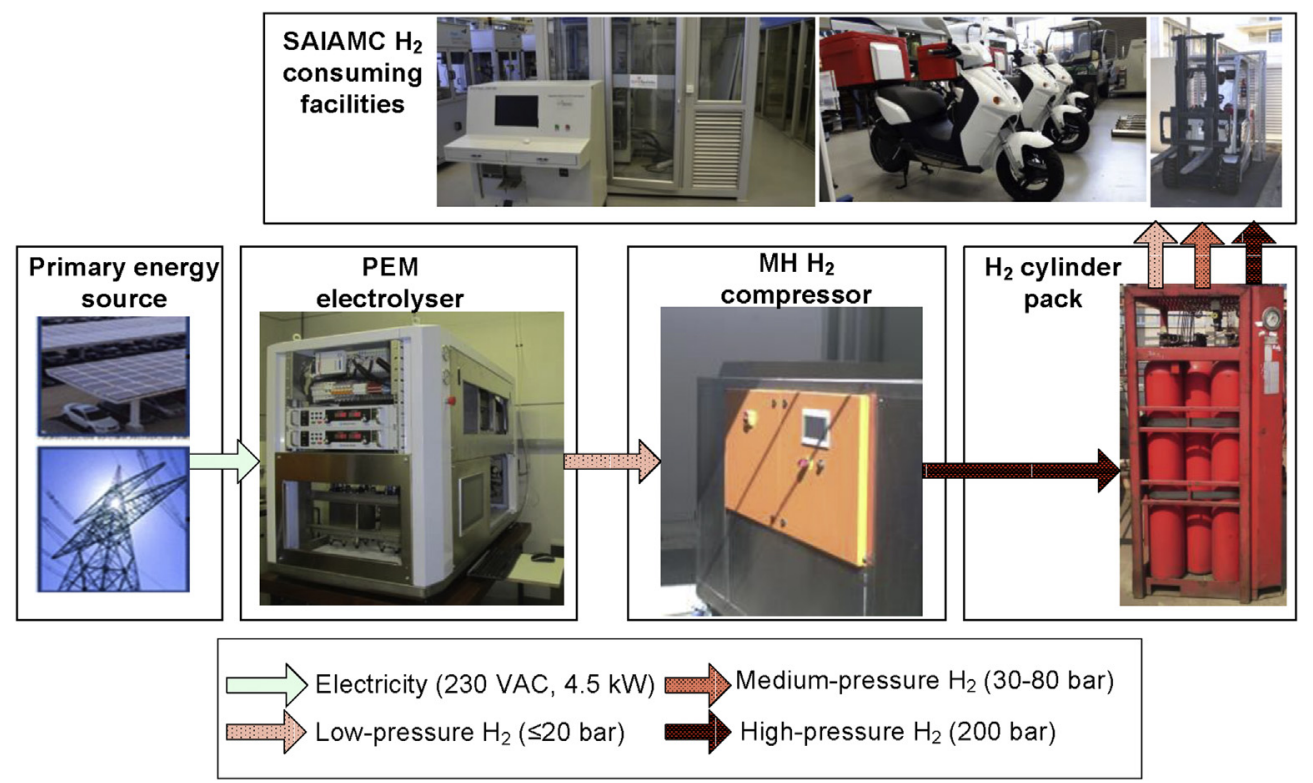

Fig. 5 - Schematic representation of hydrogen production, storage and distribution system at HySA Systems/South African Institute for Advanced Materials Chemistry (SAIAMC) research facility. Additional details about the system components are presented in Table 4 (number 2).

HYSTORE compressor is in the narrow range of the operating temperatures $\left(10-80{ }^{\circ} \mathrm{C}\right)$ that allows to use simple and inexpensive source of heat (e.g. solar collectors) to drive $\mathrm{H}_{2}$ compression. This advantage, however, has been achieved at the expense of the increase of number of stages (up to six) that is known to be detrimental from thermodynamic efficiency and reliability points of view [26]. Conversely, the $\mathrm{MH}$ compressors integrated in the operating energy storage systems presented in this study use two- (IPCP) and three-stage (HySA Systems) layouts. The problem of availability of heat with rather high temperature potential $\left(130-160^{\circ} \mathrm{C}\right)$ necessary for these developments can be solved by appropriate heat management solutions, that is a subject for future studies.

\section{Conclusions}

Metal hydride hydrogen storage and compression technologies have been shown to be efficient in small-to-medium scale energy storage systems. The approach for selection of $\mathrm{AB}_{5}$ - 
and $\mathrm{AB}_{2}$-type metal hydride materials for $\mathrm{MH}$ based hydrogen storage and compression systems developed in this work has been outlined. The approach is based on the analysis of PCT properties of the materials and takes into account useable $\mathrm{H}_{2}$ capacity for hydrogen storage or cycle productivity for $\mathrm{H}_{2}$ compression depending on temperatures and pressures of $\mathrm{H}_{2}$ absorption and desorption.

Two medium-scale energy storage systems developed under supervision of IPCP and HySA Systems have been demonstrated. The systems can use various primary sources of electricity (grid, solar panels, wind turbine) for hydrogen production by water electrolysis. The produced low-pressure hydrogen is compressed by metal hydride hydrogen compressor and supplied to gas cylinder packs (150-200 atm) as main hydrogen storage facilities. Additionally, hydrogen is collected and stored at the pressure below $100 \mathrm{~atm}$ in metal hydride hydrogen storage units. Both hydrogen storage facilities supply hydrogen to PEM fuel cell stacks, up to $30 \mathrm{~kW}$ in the electric power; the high pressure cylinder packs can also supply hydrogen for the refuelling of fuel cell vehicles and for other needs.

\section{Declaration of competing interest}

The authors declare that they have no known competing financial interests or personal relationships that could have appeared to influence the work reported in this paper.

\section{Acknowledgements}

Russian co-authors are grateful to the Ministry of Science and Higher Education for the financial support (Agreement No. 05.574.21.0209, Unique identifier RFMEFI57418X0209).

SC, SP and ML acknowledge financial support of Department of Science and Innovation (DSI) of South Africa within Hydrogen South Africa (HySA) Program, HySA Systems projects KP6-S01 and KP6-S02. ML also acknowledges support of South African National Research Foundation (NRF), grant number 109092.

\section{R E F E R E N C E S}

[1] Dell RM, Rand DAJ. Energy storage - a key technology for global energy sustainability. J Power Sources 2001;100:2-17.

[2] Weitemeyer S, Kleinhans D, Vogt T, Agert C. Integration of Renewable Energy Sources in future power systems: the role of storage. Renew Energy 2015;75:14-20.

[3] Tarasov BP, Volodin AA, Fursikov PV, Sivak AV, Kashin AM. Energy storage systems. Int Sci J Altern Energy Ecol (ISJAEE) 2014;22(162):1-12.

[4] Müller K, Arlt W. Status and development in hydrogen transport and storage for energy applications. Energy Technol 2013;1:50111. https://doi.org/10.1002/ente.201300055.

[5] Zhang F, Zhao P, Niu M, Maddy J. The survey of key technologies in hydrogen energy storage. Int J Hydrogen Energy 2016;41:14535-52.

[6] Varkaraki E, Lymberopoulos N, Zachariou A. Hydrogen based emergency back-up system for telecommunication applications. J Power Sources 2003;118:14-22.
[7] Tarasov BP, Lototskii MV, Yartys' VA. Problem of hydrogen storage and prospective uses of hydrides for hydrogen accumulation. Russ J Gen Chem 2007;77(4):694-711.

[8] Doucet G, Etiévant C, Puyenchet C, Grigoriev S, Millet P. Hydrogen-based PEM auxiliary power unit. Int J Hydrogen Energy 2009;34:4983-9.

[9] Kyriakarakos G, Dounis AI, Rozakis S, Arvanitis KG, Papadakis G. Polygeneration microgrids: a viable solution in remote areas for supplying power, potable water and hydrogen as transportation fuel. Appl Energy 2011;88:4517-26.

[10] MacA Gray E, Webb CJ, Andrews J, Shabani B, Tsai PJ, Chan SLI. Hydrogen storage for off-grid power supply. Int J Hydrogen Energy 2011;36:654-63.

[11] Fernández-Moreno J, Guelbenzu G, Martín AJ, Folgado MA, Ferreira-Aparicio P, Chaparro AM. A portable system powered with hydrogen and one single air-breathing PEM fuel cell. Appl Energy 2013;109:60-6.

[12] Lototskyy MV, Davids MW, Tolj I, Klochko YV, Satya Sekhar B, Chidziva S, Smith F, Swanepoel D, Pollet BG. Metal hydride systems for hydrogen storage and supply for stationary and automotive low temperature PEM fuel cell power modules. Int J Hydrogen Energy 2015;40:11491-7.

[13] Gonzatti F, Nizolli V, Ferrigolo FZ, Farret FA, Silva de Mello MA. Experimental hydrogen plant with metal hydrides to store and generate electrical power. Int J Emerg Elec Power Syst 2016;17(1):59-67. https://doi.org/10.1515/ijeeps-2015-0081.

[14] Parra D, Gillott M, Walker GS. Design, testing and evaluation of a community hydrogen storage system for end user applications. Int J Hydrogen Energy 2016;41:5215-29.

[15] Lototskyy MV, Tolj I, Pickering L, Sita C, Barbir F, Yartys V. The use of metal hydrides in fuel cell applications. Prog Nat Sci: Met Mater Int 2017;27:3-20.

[16] Baricco M, Bang M, Fichtner M, Hauback B, Linder M, Luetto C, Moretto P, Sgroi M. SSH2S: hydrogen storage in complex hydrides for an auxiliary power unit based on high temperature proton exchange membrane fuel cells. J Power Sources 2017;342:853-60.

[17] Han G, Kwon YK, Kim JB, Lee S, BaeJ, Cho EA, Lee BJ, Cho S, ParkJ. Development of a high-energy-density portable/mobile hydrogen energy storage system incorporating an electrolyzer, a metal hydride and a fuel cell. Appl Energy 2020;259:114175.

[18] Maeda T, Nishida K, Tange M, Takahashi T, Nakano A, Ito H, Hasegawa Y, Masuda M, Kawakami Y. Numerical simulation of the hydrogen storage with reaction heat recovery using metal hydride in the totalized hydrogen energy utilization system. Int J Hydrogen Energy 2011;36:10845-54.

[19] Song C, Klebanoff LE, Johnson TA, Chao BS, Socha AF, Oros JM, Radley CJ, Wingert S, Breit JS. Using metal hydride $\mathrm{H}_{2}$ storage in mobile fuel cell equipment: design and predicted performance of a metal hydride fuel cell mobile light. Int J Hydrogen Energy 2014;39:14896-911.

[20] Liu Z, Li Y, Bu Q, Guzy CJ, Li Q, Chen W, Wang C. Novel fuel cell stack with coupled metal hydride containers. J Power Sources 2016;328:329-35.

[21] Linder M, Mertz R, Laurien E. Experimental results of a compact thermally driven cooling system based on metal hydrides. Int J Hydrogen Energy 2010;35:7623-32.

[22] Delhomme B, Lanzini A, Ortigoza-Villalba GA, Nachev S, de Rango P, Santarelli M, Marty P, Leone P. Coupling and thermal integration of a solid oxide fuel cell with a magnesium hydride tank. Int J Hydrogen Energy 2013;38:4740-7.

[23] Lototskyy M, Nyallang Nyamsi S, Pasupathi S, Wærnhus I, Vik A, Ilea C, Yartys V. A concept of combined cooling, heating and power system utilising solar power and based on reversible solid oxide fuel cell and metal hydrides. Int J Hydrogen Energy 2018;43:18650-63.

[24] Muthukumar P, Kumar A, Raju NN, Malleswararao K, Rahman MM. A critical review on design aspects and 
developmental status of metal hydride based thermal machines. Int J Hydrogen Energy 2018;43:17753-79.

[25] Weckerle C, Nasri M, Hegner R, Linder M, Bürger I. A metal hydride air-conditioning system for fuel cell vehicles performance investigations. Appl Energy 2019;256:113957.

[26] Lototskyy MV, Yartys VA, Pollet BG, Bowman Jr RC. Metal hydride hydrogen compressors: a review. Int J Hydrogen Energy 2014;39:5818-51.

[27] Tarasov BP, Bocharnikov MS, Yanenko YB, Fursikov PV, Minko KB, Lototskyy MV. Metal hydride hydrogen compressors for energy storage systems: layout features and results of long-term tests. J Phys Energy 2020;2:024005. https://doi.org/10.1088/2515-7655/ab6465.

[28] ATLAS-H2. Advanced metal hydride tanks for integrated hydrogen applications, European Commission: CORDIS (Project ID: 251562), http://cordis.europa.eu/project/rcn/ 95383_en.html. [Accessed 5 July 2020].

[29] ATLAS-MHC. Advanced metal hydride hydrogen compressors - pilot development and market penetration, European Commission: CORDIS (Project ID 612292), http://cordis.europa. eu/project/rcn/110356_en.html. [Accessed 5 July 2020].

[30] Innovative compression solutions for efficient hydrogen mobility, the fuel cell and hydrogen joint undertaking of the European commission. https://cosmhyc.eu/. [Accessed 5 July 2020].

[31] Johnson T, et al. Metal hydride compression, US DoE hydrogen and fuel cells Program, project ID PD138. 28 march 2018. https://www.hydrogen.energy.gov/pdfs/review18/ pd138_johnson_2018_o.pdf.

[32] Sandrock G. A panoramic overview of hydrogen storage alloys from a gas reaction point of view. Journal Alloys Compds 1999;293-295:877-88.

[33] Rusanov AV, Solovey VV, Lototskyy MV. Thermodynamic features of metal hydride thermal sorption compressors and perspectives of their application in hydrogen liquefaction systems. J Phys Energy 2020;2:021007. https://doi.org/10.1088/ 2515-7655/ab7bf4.

[34] Tarasov BP. Metal-hydride accumulators and generators of hydrogen for feeding fuel cells. Int J Hydrogen Energy 2011;36:1196-9.

[35] Lototskyy M, Yartys VA. Comparative analysis of the efficiencies of hydrogen storage systems utilising solid state H storage materials. J Alloys Compd 2015;645:S365-73.

[36] Kojima Y, Kawai Y, Towata S-I, Matsunaga T, Shinozawa T, Kimbara M. Development of metal hydride with high dissociation pressure. J Alloys Compd 2006;419:256-61.

[37] Sakintuna B, Lamari-Darkrim F, Hirscher M. Metal hydride materials for solid hydrogen storage: a review. Int J Hydrogen Energy 2007;32:1121-40.

[38] Mori D, Hirose K, Haraikawa N, Takiguchi T, Shinozawa T, Matsunaga T, et al. High-pressure metal hydride tank for fuel cell vehicles. 2007. JSAE 20077268.

[39] Sujan GK, Pan Z, Li H, Liang D, Alam N. An overview on TiFe intermetallic for solid-state hydrogen storage: microstructure, hydrogenation and fabrication processes. Crit Rev Solid State Mater Sci 2019:1-18. https://doi.org/ 10.1080/10408436.2019.1652143.

[40] Bellosta von Colbe J, Ares J-R, Barale J, Baricco M, Buckley C, Capurso G, et al. Application of hydrides in hydrogen storage and compression: achievements, outlook and perspectives. Int J Hydrogen Energy 2019;44:7780-808.

[41] Kojima Y. Hydrogen storage materials for hydrogen and energy carriers. Int J Hydrogen Energy 2019;44:18179-92.

[42] Bowman Jr RC, Payzant EA, Wilson PR, Pearson DP, Ledovskikh A, Danilov D, Notten PHL, Ana K, Skorpenske HD, Wood DL. Characterization and analyses of degradation and recovery of $\mathrm{LaNi}_{4.78} \mathrm{Sn}_{0.22}$ hydrides following thermal aging. J Alloys Compd 2013;580:S207-10.
[43] Liu J, Li K, Cheng H, Yan K, Wang Y, Liu Y, Jin H, Zheng Z. New insights into the hydrogen storage performance degradation and $\mathrm{Al}$ functioning mechanism of $\mathrm{LaNi}_{5-\mathrm{x}} \mathrm{Al}_{\mathrm{x}}$ alloys. Int J Hydrogen Energy 2017;42:24904-14.

[44] Odysseos M, De Rango P, Christodoulou CN, Hlil EK, Steriotis T, Karagiorgis G, et al. The effect of compositional changes on the structural and hydrogen storage properties of ( $\mathrm{La}-\mathrm{Ce}) \mathrm{Ni}_{5}$ type intermetallics towards compounds suitable for metal hydride hydrogen compression. J Alloys Compd 2013;580:S268-70.

[45] Tarasov BP, Bocharnikov MS, Yanenko YB, Fursikov PV, Lototskyy MV. Cycling stability of $\mathrm{RNi}_{5}(\mathrm{R}=\mathrm{La}, \mathrm{La}+\mathrm{Ce})$ hydrides during the operation of metal hydride hydrogen compressor. Int J Hydrogen Energy 2018;43:4415-27.

[46] Mitrokhin SV. Regularities of hydrogen interaction with multicomponent $\mathrm{Ti}(\mathrm{Zr})-\mathrm{Mn}-\mathrm{V}$ Laves phase alloys. J Alloys Compd 2005;404-406:384-7.

[47] Pickering L, Lototskyy MV, Davids MW, Sita C, Linkov V. Induction melted $\mathrm{AB}_{2}$-type metal hydrides for hydrogen storage and compression applications. Mater Today: Proceedings 2018;5(4):10470-8.

[48] Shilov AL, Padurets LN, Kost ME. Thermodynamics of hydrides of intermetallic compounds of transition metals. Russ J Phys Chem 1985;59(8):1857-75.

[49] Zotov T, Movlaev E, Mitrokhin S, Verbetsky V. Interaction in (Ti,Sc) $\mathrm{Fe}_{2}-\mathrm{H}_{2}$ and $(\mathrm{Zr}, \mathrm{Sc}) \mathrm{Fe}_{2}-\mathrm{H}_{2}$ systems. J Alloys Compd 2008;459:220-4.

[50] Zotov TA, Sivov RB, Movlaev EA, Mitrokhin SV, Verbetsky VN. IMC hydrides with high hydrogen dissociation pressure. J Alloys Compd 2011;509S:S839-43.

[51] Davids MW, Lototskyy M, Pollet BG. Manufacturing of hydride-forming alloys from mixed titanium - iron oxide. Adv Mater Res 2013;746:14-22.

[52] Wijayanti ID, Denys R, Suwarno Volodin AA, Lototskyy MV, Guzik MN, et al. Hydrides of Laves type Ti-Zr alloys with enhanced H storage capacity as advanced metal hydride battery anodes. J Alloys Compd 2020;828:154354.

[53] Yao Z, Liu L, Xiao X, Wang C, Jiang L, Chen L. Effect of rare earth doping on the hydrogen storage performance of $\mathrm{Ti}_{1.02} \mathrm{Cr}_{1.1} \mathrm{Mn}_{0.3} \mathrm{Fe}_{0.6}$ alloy for hybrid hydrogen storage application. J Alloys Compd 2018;73:524-30.

[54] Ulmer U, Dieterich M, Pohl A, Dittmeyer R, Linder M, Fichtner M. Study of the structural, thermodynamic and cyclic effects of vanadium and titanium substitution in laves-phase $\mathrm{AB}_{2}$ hydrogen storage alloys. Int J Hydrogen Energy 2017;42:20103-10.

[55] Fashu S, Lototskyy M, Davids MW, Pickering L, Linkov V, Tai S, et al. A review on crucibles for induction melting of titanium alloys. Mater Des 2020;186:108295.

[56] Lototskyy MV. New model of phase equilibria in metal hydrogen systems: features and software. Int J Hydrogen Energy 2016;41:2739-61.

[57] Nasako K, Ito Y, Hiro N, Osumi M. Stress on a reaction vesse] by the swelling of a hydrogen absorbing alloy. J Alloys Compd 1998;264:271-6.

[58] Lototskyy M, Tolj I, Klochko Y, Davids MW, Swanepoel D, Linkov V. Metal hydride hydrogen storage tank for fuel cell utility vehicles. Int J Hydrogen Energy 2020;45:7958-67.

[59] Hirscher M, Yartys VA, Baricco M, Bellosta von Colbe J, Blanchard D, Bowman Jr RC, et al. Materials for hydrogenbased energy storage - past, recent progress and future outlook. J Alloys Compd 2020;827:153548.

[60] ATLAS-MHC: Advanced metal hydride hydrogen compressors - pilot development and market penetration; http://www2 ipta.demokritos.gr/atlas-mhc/.

[61] Stamatakis E, Zoulias E, Tzamalis G, Massina Z, Analytis V, Christodoulou C, Stubos A. Metal hydride hydrogen compressors: current developments \& early markets. Renew Energy 2018;127:850-62. 